\title{
PENGARUH SISTEM INFORMASI MANAJAMEN PENDIDIKAN DAN KOMPETENSI SOSIAL GURU TERHADAP KEPUASAN ORANG TUA PESERTA DIDIK SD ISLAM AL AZHAR 2 PASAR MINGGU
}

\author{
Abdullah \\ Program Pascasarjana Institut PTIQ Jakarta \\ Email : abdullah.sadece67@gmail.com
}

\begin{abstract}
ABSTRAK
Penelitian ini bertujuan untuk mengetahui dan menguji data-data empirik terkait pengaruh sistem informasi manajemen pendidikan dan kompetensi sosial guru terhadap kepuasan orang tua peserta didik secara terpisah maupun simultan. Dalam penelitian ini, penulis menggunakan metode kuantitatif dengan pendekatan korelasional terhadap data-data kuantitatif yang diperoleh dari objek penelitian yaitu orang tua peserta didik SD Islam Al-Azhar 2 Pasar Minggu. Pengumpulan data dilakukan dengan menggunakan teknik angket atau kuesioner untuk mendapatkan data yang bersifat pendapat atau persepsi, yang dilanjutkan dengan pendalaman melalui wawancara dan observasi langsung ke sumber data. Jenis analisis yang digunakan adalah analisis korelasi dan regresi yang dijabarkan secara deskriptif. Hasil penelitian menunjukkan bahwa terdapat pengaruh yang positif dan signifikan antara sistem informasi manajemen pendidikan dan kompetensi sosial guru dengan kepuasan orang tua peserta didik baik secara terpisah maupun simultan. Adapun setiap peningkatan satu unit skor dari sistem informasi manajemen pendidikan dan kompetensi sosial guru akan mempengaruhi skor kepuasan orang tua.
\end{abstract}

Kata kunci: sistem informasi manajemen pendidikan, kompetensi sosial guru, kepuasan orang tua. 


\section{PENDAHULUAN}

Peningkatan kualitas dan mutu layanan adalah sesuatu yang perlu dilaksanakan pada lembaga pendidikan agar memiliki daya saing dan mampu mencapai kepuasan pelanggannya. Indonesia masih memiliki tantangan dan persoalan utama dalam peningkatan kualitas pendidikan. Laporan "Local Governance.and.Education.Performace: Survei of Quality of Local Education Gorvance in 50 Indonesian Districtc" yang dilakukan oleh Bank dunia (2013) menunjukkan Pemerintah daerah memiliki keberagaman dalam kualitas tata kelola dalam mewujudkan pelayanan pendidikan yang efektif. Dan yang menjadi hal menarik pada laporan tersebut ialah pelayanan manajemen pendidikan yang masih buruk. ${ }^{1}$

Hakekat dari adanya peningkatan mutu layanan sekolah ialah untuk meningkatkan kepuasan pelanggan. Dalam menentukan keberhasilan suatu layanan yang berbentuk jasa atau produk, kepuasan pelanggan adalah salah satu indikator yang harus diperhatikan dalam mencapai tujuan. ${ }^{2}$ Kepuasan pelanggan merupakan perasaan yang dimiliki oleh pelanggan mengenai hasil pelayanan yang diterima. Sebagaimana pentingnya pelanggan bagi sebuah perusahaan, pelanggan juga memiliki peranan yang penting bagi lembaga pendidikan. Hal tersebut disebabkan lembaga pendidikan memiliki hubungan yang erat dengan pelanggan.

Selain peserta didik, orang tua merupakan pelanggan sekolah yang harus diberikan pelayanan secara optimal. Kepuasan orang tua peserta didik dapat dicapai melalui program-program dan layanan yang bermutu. ${ }^{3}$ Orang tua memiliki peranan yang penting bagi sekolah. Selain memilih sekolah bagi anak-anaknya, orang tua akan menjalin hubungan dengan sekolah dilandasi oleh kepuasan terhadap hasil yang mereka rasakan. Adapun kenyataannya, kepuasan orang tua masih belum tercapai dikarenakan kualitas layanan sekolah masih jauh dari harapan.

Perkembangan teknologi informasi dan komunikasi yang pesat saat ini mengharuskan sekolah untuk bisa beradaptasi dan bersaing dalam memberikan layanan informasi dan komunikasi yang efektif dan efisien. Layanan tersebut dapat diwujudkan apabila sekolah memiliki sistem informasi manajemen pendidikan yang baik. Namun tidak dipungkiri bahwa banyak sekolah yang belum mampu menyediakan SIM Pendidikan dengan baik disebabkan sumber daya yang belum memadai.

SIM Pendidikan merupakan sistem informasi yang berfungsi mengelola informasi pendidikan. Sistem informasi manajemen pendidikan adalah perpaduan antara sumber daya manusia dan aplikasi teknologi informasi untuk memilih, menyimpan, mengolah dan mengambil kembali data dalam rangka mendukung proses pengambilan keputusan dalam bidang pendidikan. ${ }^{4}$ Keterlibatan SIM juga berperan agar kegiatan dan layanan pendidikan dapat terlaksana dengan efektif dan efisien.

Selain harus memiliki SIM Pendidikan yang mumpuni. guru harus memiliki kompetensi sosial yang baik dalam memenuhi kebutuhan orang tua

${ }^{1}$ Ahmad Baesowi, Calak Edu 3: Esai-esai Pendidikan 2012-2014 (Tanggerang: Pustaka Alvabet, 2015), 76.

${ }^{2}$ M.N. Nasution, Manajemen Mutu Terpadu (Jakarta: Ghalia Indonesia, 2004), 44.

3 Nanang Fattah, Analisis Kebijakan Pendidikan (Bandung: Remaja Kosdakarya, 2014), 90.

4 Eti Rochaety dan Pontjorini Rahayuningsih, Sistem Informasi Manajemen Pendidikan (Jakarta: Bumi Aksara, 2008), 13. 
peserta didik. Banyaknya interaksi yang terjalin mengharuskan guru memiliki kemampuan untuk bisa berkomunikasi dengan baik. Tidak dipungkiri seorang guru memiliki masalah yang sangat beragam, tidak hanya menyelesaikan masalah pribadi guru juga dituntut untuk bisa menghadapi masalah yang datang dari anak maupun orang tua. Ada beberapa faktor yang menyebabkan komunikasi guru dan orang tua menjadi terhambat seperti ketidaktahuan maupun keterlambatan informasi tentan apa yang terjadi di sekolah, perhatian orang tua terhadap kegiatan peserta didik, dan terlambatnya tanggapan dalam proses komunikasi. ${ }^{5}$ Hal tersebut menjadi permasalahan yang harus dapat diselesaikan dengan baik.

Dengan demikian, sebagai guru yang profesional sudah menjadi hal mendasar bagi guru untuk memiliki kompetensi. Di antaranya ialah kompetensi sosial. Kompetensi ini tidak kalah pentingnya dengan kompetensi lainnya seperti pedagogik, profesional dan intelektual. Dengan kompetensi sosial ini guru diharapkan bisa berkomunikasi dengan berbagai media yang ada, baik secara langsung maupun tidak langsung, memanfaatkan teknologi komunikasi dan informasi secara fungsional, dan mampu bergaul secara efektif dengan individu yang ada di dalam maupun di luar organisasi. ${ }^{6}$

Berdasarkan pemaparan di atas, maka permasalahan yang dikaji pada penelitian ini berhubungan dengan terbatasnya penggunaan sistem informasi manajemen pendidikan dan kompetensi sosial guru dalam layanan informasi dan komunikasi yang berdampak pada tidak tercapainya kepuasan orang tua peserta didik. Adapun dalam bidang sistem informasi manajemen pendidikan peneliti berfokus pada aplikasi salam al-Azhar yang merupakan program berbasis sistem informasi manajemen yang digabungkan dengan layanan finansial technology. Layanan Fintech ini merupakan inovasi dalam layanan keuangan dengan sentuhan teknologi modern yang dapat digunakan dalam teknologi mobile, baik bersistem operasi android maupun IOS.

Mengacu pada hal tersebut, secara umum masalah utama dalam penelitian ini dapat dirumuskan yaitu pengaruh sistem informasi manajemen pendidikan dan kompetensi sosial guru terhadap kepuasan peserta didik di SD Islam Al-Azhar 2 Pasar Minggu.

\section{METODE}

Dalam penelitian ini peneliti menggunakan jenis penelitian kuantitatif. Adapun populasi dalam penelitian ini adalah seluruh orang tua peserta didik SD al-Azhar 2 Pasar Minggu dengan populasi terjangkau berjumlah 202 responden dengan sampel yang berjumlah 133 responden. Pengumpulan data dilakukan dengan menggunakan teknik angket atau kuesioner, wawancara, dan observasi langsung dengan narasumber.

Dalam skala pengukuran Peneliti menggunakan skala likert dengan bentuk angket pada lima alternatif jawaban. Sebelum angket digunakan dalam pengumpulan data, maka terlebih dahulu diuji validitas dan reliabilitasnya terhadap alat ukur (angket) peneliti yang akan dipergunakan. Validitas instrumen dapat diukur melalui teknik korelasi Product Moment Pearson, yaitu dengan membandingkan koefisien korelasi antara skor butir dengan skor total. Instrumen

${ }^{5}$ Khoiruddin Bashori, Pengembangan Kapasitas Guru (Tanggerang: Pustaka Alvabet, 2015), 39.

${ }^{6}$ Rofa'ah, Guru dalam kegiatan pembelajaran dalam perspektif Islam (Yogyakarta: Deepublish, 2016), 49. 
dinyatakan valid jika koefisien korelasi hasil perhitungan lebih besar dari $r$ tabel $\left(\mathrm{r}_{\text {hitung }}>\mathrm{r}_{\text {tabel }}\right)$. Sedangkan reliabilitas instrumen dapat diukur dengan menggunakan rumus AlfhaCronbach. Instrumen dapat dikatakan reliabel (ajeg/konsisten) jika memiliki tingkat koefisien $\geq 0,7$.

Sebelum melalukan pengujian hipotesis data yang diperoleh dari penelitian akan di analisis terlebih dahulu untuk memenuhi persyaratan. Pengujiannya yaitu uji normlitas distribusi galat taksiran tiap variable (menggunakan SPSS dan Uji Lilliefors), uji homogentias varians kelompok (menggunakan Uji Barlet dan uji linearitas Persamaan regresi (menggunakan uji regresi SPSS).

Pengujian terhadap hipotesis penelitian dengan menggunakan beberapa Teknik. Pertama, Teknik Korelasi sederhana. Teknik ini disebut juga Pearson Pruduct Moment; teknik ini bertujuan untuk mengetahui ada atau tidaknya hubungan dari variabel independen atau bebas secara sendiri sendiri terhadap variabel dependen atau terikat. Kedua, Teknik korelasi ganda. Teknik ini bertujuan untuk mengetahui ada atau tidaknya hubungan dari variabel independen atau bebas secara bersama-sama terhadap variabel dependen atau terikat. Ketiga.Teknik regresi sederhana dan ganda. Teknik ini digunakan untuk menggambarkan pola atau fungsi hubungan antar variabel terikat dan variabel bebas secara bersama sama atau sendiri-sendiri.

\section{HASIL DAN PEMBAHASAN}

\subsection{Pengujian Persyaratan analisis Hipotesis Penelitian}

\subsubsection{Uji Normalitas Galat taksiran}

Setelah menguji menggunakan SPSS, galat taksiran untuk persamaan regresi $\hat{\mathrm{Y}}$ atas $\mathrm{X}_{1}$ menunjukkan Asymp. Sig (2-tailed) atau nilai $\mathrm{P}=0,059>0,050(5 \%)$ atau $\mathrm{Z}_{\text {hitung }} 0,076$ dan $\mathrm{Z}_{\text {tabel }}$ pada taraf kepercayaan/signifikansi $\alpha=0,05$ adalah $0,170\left(Z_{\text {hitung }} 0,076<Z_{\text {tabel }}\right.$ 0,170), Dengan demikian dapat diinterpretasikan / ditafsirkan bahwa persyaratan normalitas distribusi galat taksiran terpenuhi dengan kata lain galat taksiran persamaan regresi $\hat{Y}$ atas $X_{1}$ adalah berdistribusi normal.

Galat taksiran untuk persamaan regresi $\hat{Y}$ atas $X_{2}$ menunjukkan $Z_{\text {hitung }} 0,111$ dan $Z_{\text {tabel }}$ pada taraf kepercayaan/signifikansi $\alpha=0,05$ adalah 0,170 ( $\left.Z_{\text {hitung }} 0,111<Z_{\text {tabel }} 0,170\right)$, Dengan demikian dapat diinterpretasikan/ditafsirkan bahwa persyaratan normalitas distribusi galat taksiran terpenuhi dengan kata lain galat taksiran persamaan regresi $\hat{Y}$ atas $X_{2}$ adalah berdistribusi normal.

Galat taksiran untuk persamaan regresi $\hat{Y}$ atas $X_{1} X_{2}$ menunjukkan Asymp. Sig (2-tailed) atau nilai $\mathrm{P}=0,053>0,05(5 \%)$ atau $\mathrm{Z}_{\text {hitung }}$ 0,077 dan $\mathrm{Z}_{\text {tabel }}$ pada taraf kepercayaan/signifikansi $\alpha=0,05$ adalah 0,170 ( $Z_{\text {hitung }} 0,077<Z_{\text {tabel }} 0,170$ ). Dengan demikian dapat diinterpretasikan/ ditafsirkan bahwa persyaratan normalitas distribusi galat taksiran terpenuhi dengan kata lain galat taksiran persamaan regresi $\hat{Y}$ atas $X_{1}$ dan $X_{2}$ adalah berdistribusi normal. 


\begin{tabular}{|c|c|c|c|c|}
\hline \multirow{2}{*}{$\begin{array}{c}\text { Galat Taksiran } \\
\text { Regresi Y atas }\end{array}$} & \multicolumn{3}{|c|}{ Perbandingan } & \multirow{2}{*}{ Keterangan } \\
\cline { 2 - 5 } & Zhitung & $=$ & Ztabel & \\
\hline X1 & 0,076 & $<$ & 0,170 & Normal \\
\hline X2 & 0,111 & $<$ & 0,170 & Normal \\
\hline X1 \& X2 & 0,077 & $<$ & 0,170 & Normal \\
\hline
\end{tabular}

\subsubsection{Uji Linieritas Persamaan Regresi}

Setelah menguji menggunakan SPSS, maka untuk persamaan regresi $\mathrm{Y}$ atas $\mathrm{X}_{1}$ menunjukkan nilai $\mathrm{P}$ Sig $=0,051>0,05(5 \%)$ atau $F_{\text {hitung }}=1,50$ dan $F_{\text {tabel }}$ dengan $\mathrm{dk}$ pembilang $50 \mathrm{dan} \mathrm{dk}$ penyebut 81 dan pada taraf kepercayaan (signifikansi) $\alpha=$ 0,05.adalah 1,54 ( $\left.F_{\text {hitung }} 1,504<F_{\text {tabel }} 1,540\right)$. Dengan demikian, maka dapat diinterpretasikan/ditafsirkan bahwa persyaratan linearitas terpenuhi atau model persamaan regresi $\hat{Y}$ atas $X_{1}$ adalah linear.

Dari tabel $4.15 \mathrm{di}$ atas, maka untuk persamaan regresi $\mathrm{Y}$ atas $\mathrm{X}_{2}$ menunjukkan nilai $\mathrm{P}$ Sig $=0,537>0,05(5 \%)$ atau $\mathrm{F}_{\text {hitung }}=$ 0,968 dan $F_{\text {tabel }}$ dengan $\mathrm{dk}$ pembilang $43 \mathrm{dan} \mathrm{dk}$ penyebut 88 dan pada taraf kepercayaan (signifikansi) $\alpha=0,05$.adalah 1,54 ( $\left.F_{\text {hitung }} 0,968<F_{\text {tabel }} 1,54\right)$. Dengan demikian, maka dapat diinterpretasikan/ditafsirkan bahwa persyaratan linearitas terpenuhi atau model persamaan regresi $\hat{Y}$ atas $X_{2}$ adalah linear.

\begin{tabular}{|c|c|c|c|c|}
\hline \multirow{2}{*}{$\begin{array}{c}\text { Persamaan } \\
\text { Regresi Y } \\
\text { atas }\end{array}$} & \multicolumn{3}{|c|}{ Perbandingan } & \multirow{2}{*}{ Keterangan } \\
\cline { 2 - 4 } & $\mathbf{F}_{\text {hitung }}$ & $=$ & $\mathbf{F}_{\text {tabel }}$ & \\
\hline $\mathrm{X} 1$ & 1,504 & $<$ & 1,540 & Linear \\
\hline $\mathrm{X} 2$ & 0,968 & $<$ & 1,540 & Linear \\
\hline
\end{tabular}

\subsubsection{Uji Asumsi Heteroskedas-tisitas Regresi}

Berdasarkan gambar di bawah, ternyata titik-titik menyebar di atas dan bawah titik nol pada sumbu Y, dan tidak membuat pola tertentu. Dengan demikian, dapat diinterpretasikan atau ditafsirkan bahwa tidak terjadi heteroskedastisitas atau dengan kata lain varian kelompok kepuasan orang tua (Y) atas sistem informasi manajemen pendidikan $\left(X_{1}\right)$ dan kompetensi sosial guru $\left(X_{2}\right)$ baik secara masing-masing atau bersama-sama adalah homogen.

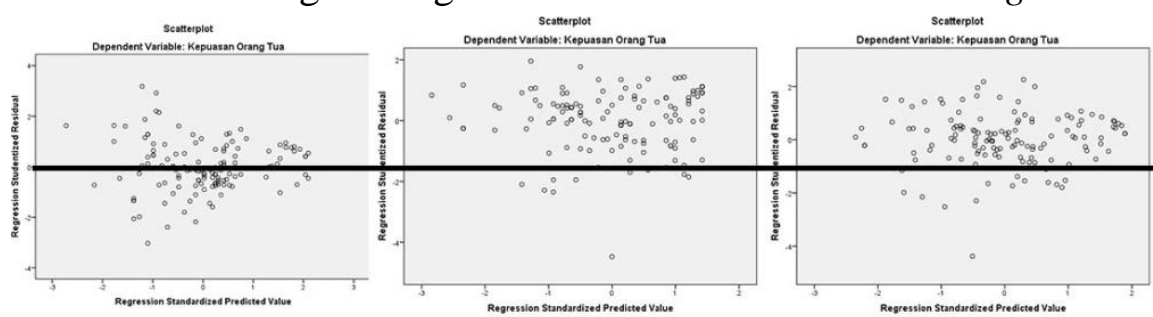




\subsection{Pengujian Hipotesis Penelitian}

Berdasarkan hasil pengujian hipotesis yang telah diuraikan di atas, maka secara keseluruhan temuan dalam penelitian ini dapat menjawab rumusan masalah yang telah dipaparkan di atas, adapun hasil dari analisa data menggunakan metode statistik maka dapat dideskripsikan hasil penelitian ini sebagai berikut:

3.2.1 Pengaruh Sistem Informasi Manajemen Pendidikan terhadap Kepuasan Orang Tua

\begin{tabular}{|c|c|c|c|}
\hline \multicolumn{4}{|c|}{ Correlations } \\
\hline & & Sistem Informasi & Kepuasan \\
\hline & & Manajemen & Orang Tua \\
\hline \multirow{3}{*}{$\begin{array}{l}\text { Sistem Informasi } \\
\text { Manajemen }\end{array}$} & Pearson Correlation & 1 & $670^{* *}$ \\
\hline & Sig. (1-tailed) & &, 000 \\
\hline & $\mathrm{N}$ & 133 & 133 \\
\hline \multirow{3}{*}{$\begin{array}{l}\text { Kepuasan Orang } \\
\text { Tua }\end{array}$} & Pearson Correlation & ,670 & 1 \\
\hline & Sig. (1-tailed) &, 000 & \\
\hline & $\mathrm{N}$ & 133 & 133 \\
\hline
\end{tabular}

${ }^{*}$. Correlation is significant at the 0.01 level (1-tailed).

Berdasarkan tabel tersebut tentang pengujian hipotesis $\rho_{\mathrm{y} 1}$ di atas, menunjukkan bahwa pada tingkat kepercayaan 99\% $(\alpha=0,01)$ diperoleh koefisien korelasi sederhana Pearson correlation $\left(\rho_{\mathrm{y} 1}\right)$ adalah 0,670. Dengan demikian, maka Ho ditolak dan Hi diterima, yang berarti bahwa terdapat pengaruh positif dan signifikan sistem informasi manajemen pendidikan terhadap kepuasan orang tua.

\begin{tabular}{|c|c|c|c|c|}
\hline \multicolumn{5}{|c|}{ Model Summary } \\
\hline Model & $\mathrm{R}$ & R Square & $\begin{array}{c}\text { Adjusted R } \\
\text { Square }\end{array}$ & $\begin{array}{l}\text { Std. Error of } \\
\text { the Estimate }\end{array}$ \\
\hline 1 &, $670^{\mathrm{a}}$ & ,449 & ,445 & 11,241 \\
\hline
\end{tabular}

Adapun besarnya pengaruh ditunjukkan oleh koefisien determinasi $\mathrm{R}^{2}(R$ square $)=0,449$ yang berarti bahwa sistem informasi manajemen pendidikan memberikan pengaruh terhadap kepuasan orang tua sebesar $44,9 \%$ dan sisanya yaitu $55,1 \%$ ditentukan oleh faktor lainnya.

\begin{tabular}{|c|c|c|c|c|c|c|}
\hline \multicolumn{7}{|c|}{ Coefficients $^{a}$} \\
\hline & & \multirow{2}{*}{\multicolumn{2}{|c|}{$\begin{array}{c}\text { Unstandardized } \\
\text { Coefficients }\end{array}$}} & \multirow{3}{*}{$\begin{array}{c}\text { Standardized } \\
\text { Coefficients } \\
\text { Beta } \\
\end{array}$} & \multirow[b]{3}{*}{$t$} & \multirow[b]{3}{*}{ Sig. } \\
\hline & & & & & & \\
\hline \multicolumn{2}{|l|}{ Model } & $B$ & Std. Error & & & \\
\hline \multirow[t]{4}{*}{1} & (Constant) & 59,045 & 6,253 & & 9,443 & , 000 \\
\hline & Sistem & ,567 &, 055 & ,670 & 10,335 &, 000 \\
\hline & Informasi & & & & & \\
\hline & Manajemen & & & & & \\
\hline
\end{tabular}


Memperhatikan hasil analisis regresi sederhana, menunjukkan persamaan regresi sederhana (unstandardized coefficients $B$ ) $\hat{Y}=59$, $045+0,567 \mathrm{X}_{1}$ yang berarti bahwa setiap peningkatan satu unit skor sistem informasi manajemen pendidikan akan mempengaruhi peningkatan skor kepuasan orang tua sebesar 0,567.

Berdasarkan analisis tersebut bahwa sistem informasi manajemen pendidikan adalah salah satu faktor yang mempengaruhi kepuasan orang tua. Sistem informasi Manajemen Pendidikan yang baik sebagai layanan informasi yang efektif akan menambah kepuasan orang tua. Sejalan dengan hasil penelitian tersebut Yakub dan Vico Hisbanarto ${ }^{7}$ dalam bukunya mengemukakan bahwa SIM Pendidikan berperan sebagai layanan informasi pendidikan dalam pencapaian kepuasan pelanggan, dengan cara memenuhi kebutuhan pengguna dan melakukan perbaikan secara terus menerus atas layanan yang diberikan. SIM merupakan alat pendukung organisasi pendidikan mampu memberikan layanan informasi sesuai dengan kebutuhan pengguna, mudah didapat, dan berdampak pada peningkatan mutu pendidikan.

3.2.2 Pengaruh Kompetensi Sosial Guru terhadap Kepuasan Orang Tua

\begin{tabular}{|c|c|c|c|}
\hline \multicolumn{4}{|c|}{ Correlations } \\
\hline & & Sistem Informasi & Kompetensi \\
\hline & & Manajemen & Sosial Guru \\
\hline \multirow{3}{*}{$\begin{array}{l}\text { Sistem Informasi } \\
\text { Manajemen }\end{array}$} & Pearson Correlation & 1 &, $546^{* *}$ \\
\hline & Sig. (1-tailed) & &, 000 \\
\hline & $\mathrm{N}$ & 133 & 133 \\
\hline \multirow{3}{*}{$\begin{array}{l}\text { Kompetensi Sosial } \\
\text { Guru }\end{array}$} & Pearson Correlation &, $546^{* *}$ & 1 \\
\hline & Sig. (1-tailed) & ,000 & \\
\hline & $\mathrm{N}$ & 133 & 133 \\
\hline
\end{tabular}

**. Correlation is significant at the 0.01 level (1-tailed).

Berdasarkan tabel di atas tentang pengujian hipotesis $\rho_{\mathrm{y} 2}$ di atas, menunjukkan bahwa pada tingkat kepercayaan 99\% $(\alpha=0,01)$ diperoleh koefisien korelasi sederhana Pearson correlation $\left(\rho_{\mathrm{y} 1}\right)$ adalah 0,546. Dengan demikian, maka Ho ditolak dan Hi diterima, yang berarti bahwa terdapat pengaruh positif dan signifikan kompetensi sosial guru terhadap kepuasan orang tua.

\begin{tabular}{|c|c|c|c|c|}
\hline \multicolumn{5}{|c|}{ Model Summary } \\
\hline Model & $\mathrm{R}$ & R Square & $\begin{array}{l}\text { Adjusted R } \\
\text { Square }\end{array}$ & $\begin{array}{c}\text { Std. Error of the } \\
\text { Estimate }\end{array}$ \\
\hline 1 &, $747^{a}$ & ,558 & ,554 & 10,074 \\
\hline
\end{tabular}

7 Yakub, Vico Hisbanarto, Sistem Informasi Manajemen Pendidikan (Yogyakarta: Graha Ilmu, 2014), 86. 
Adapun besarnya pengaruh ditunjukkan oleh koefisien determinasi $\mathrm{R}^{2}$ ( $R$ square $)=0,558$, yang berarti bahwa kompetensi sosial guru memberikan pengaruh terhadap kepuasan orang tua sebesar 55,8\% dan sisanya yaitu 44,2\% ditentukan oleh faktor lainnya.

Adapun arah pengaruh atau koefisien regresi sederhana kepuasan orang tua atas kompetensi sosial guru, adalah sebagai berikut:

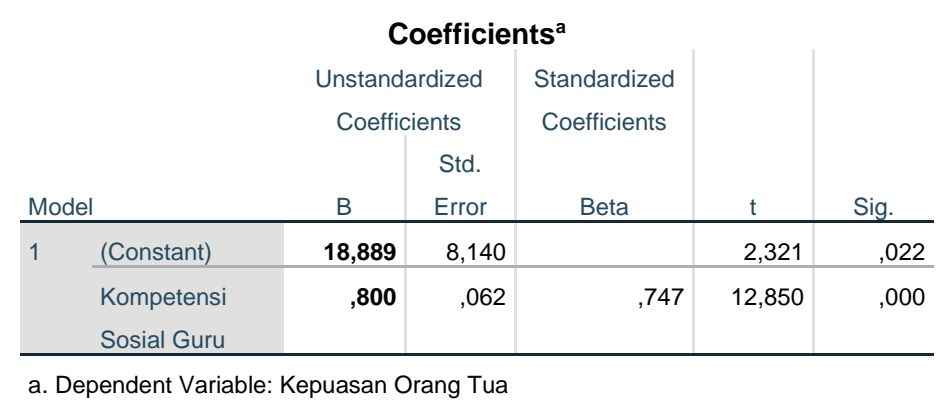

Memperhatikan hasil analisis regresi sederhana, menunjukkan persamaan regresi sedehana (unstandardized coefficients $B$ ) $\hat{\mathrm{Y}}=$ $18,889+0,800 \mathrm{X}_{2}$ yang berarti bahwa setiap peningkatan satu unit skor kompetensi sosial guru akan mempengaruhi peningkatan skor kepuasan orang tua sebesar 0,80

Berdasarkan analisis tersebut bahwa Kompetensi Sosial Guru merupakan salah satu faktor yang mempengaruhi Kepuasan Orang Tua. Peningkatan Kompetensi Sosial Guru akan diikuti dengan peningkatan Kepuasan Orang Tua, begitu pun sebaliknya. Hal ini sesuai dengan apa yang dikemukakan oleh James J. Stapleton bahwa komunikasi yang baik dan efektif merupakan suatu fondasi, dasar dari memastikan kepuasan pelanggan. Sama pentingnya, komunikasi yang baik menumbuhkan iklim rasa saling percaya yang dibutuhkan untuk menciptakan arus informasi terbuka. ${ }^{8}$

\subsubsection{Pengaruh Sistem Informasi Manajemen Pendidikan dan Kompetensi Sosial Guru terhadap Kepuasan Orang Tua}

\begin{tabular}{|c|c|c|c|c|}
\hline \multicolumn{5}{|c|}{ Model Summary } \\
\hline Model & $\mathrm{R}$ & R Square & $\begin{array}{c}\text { Adjusted R } \\
\text { Square }\end{array}$ & $\begin{array}{c}\text { Std. Error of the } \\
\text { Estimate }\end{array}$ \\
\hline 1 &, $810^{a}$ & ,656 & ,650 & 8,920 \\
\hline
\end{tabular}

Berdasarkan tabel 4.24 tentang pengujian hipotesis $\mathrm{R}_{\mathrm{y} .1 .2}$ di atas, menunjukkan bahwa pada tingkat kepercayaan 99\% $(\alpha=0,01)$ diperoleh koefisien korelasi ganda Pearson correlation $\left(\mathrm{R}_{\mathrm{y} .1 .2}\right)$ adalah 0,810. Dengan demikian, maka Ho ditolak dan Hi diterima,

8 James J. Stapleton, Executive' Guide To Knowledge Management: Puncak Keunggulan Kompetitif (Jakarta: Erlangga, 2003), 117. 
yang berarti bahwa terdapat pengaruh positif dan sangat signifikan sistem informasi manajemen pendidikan dan kompetensi sosial guru secara bersama-sama terhadap kepuasan orang tua.

\begin{tabular}{|c|c|c|c|c|}
\hline \multicolumn{5}{|c|}{ Model Summary ${ }^{b}$} \\
\hline Model & $\mathrm{R}$ & R Square & $\begin{array}{c}\text { Adjusted R } \\
\text { Square } \\
\end{array}$ & $\begin{array}{c}\text { Std. Error of the } \\
\text { Estimate }\end{array}$ \\
\hline 1 &, $810^{a}$ & ,656 & 650 & 8,920 \\
\hline
\end{tabular}

Adapun besarnya pengaruh ditunjukkan oleh koefisien determinasi $\mathrm{R}^{2}(R$ square $)=0,656$ yang berarti bahwa sistem informasi manajemen pendidikan dan kompetensi sosial guru secara bersamasama memberikan pengaruh terhadap kepuasan orang tua sebesar 65,6\% dan sisanya yaitu 34,4\% ditentukan oleh faktor lainnya.

Adapun arah pengaruh atau koefisien regresi ganda kepuasan orang tua atas sistem informasi manajemen pendidikan dan kompetensi sosial guru secara bersama-sama adalah sebagai berikut:

\begin{tabular}{|c|c|c|c|c|c|c|}
\hline & & Co & efficients & & & \\
\hline & & $\begin{array}{r}\text { Unstan } \\
\text { Coeff }\end{array}$ & $\begin{array}{l}\text { dardized } \\
\text { icients }\end{array}$ & $\begin{array}{c}\text { Standardize } \\
\text { d } \\
\text { Coefficients }\end{array}$ & & \\
\hline & & $\mathrm{B}$ & Std. Error & Beta & $\mathrm{t}$ & Sig. \\
\hline 1 & (Constant) & 11,706 & 7,304 & & 1,603 & ,111 \\
\hline & $\begin{array}{l}\text { Sistem Informasi } \\
\text { Manajemen }\end{array}$ & ,316 & ,052 & ,374 & 6,088 &, 000 \\
\hline & $\begin{array}{l}\text { Kompetensi } \\
\text { Sosial Guru }\end{array}$ &, 581 & ,066 &, 543 & 8,833 &, 000 \\
\hline
\end{tabular}

a. Dependent Variable: Kepuasan Orang Tua

Memperhatikan hasil analisis regresi sederhana, menunjukkan persamaan regresi (unstandardized coefficients $B$ ) $\hat{Y}=11,706+$ $0,316 X_{1}+0,581 X_{2}$ yang berarti bahwa setiap peningkatan satu unit skor sistem informasi manajemen pendidikan dan kompetensi sosial guru secara bersama-sama, akan mempengaruhi peningkatan skor kepuasan orang tua sebesar 0,897 .

Berdasarkan analisis tersebut bahwa sistem informasi manajemen pendidikan dan kompetensi sosial guru secara bersama-sama merupakan faktor yang mempengaruhi kepuasan orang tua. Sistem Informasi Manajemen Pendidikan yang tepat dan baik akan diikuti dengan peningkatan kepuasan orang tua siswa, dan peningkatan kompetensi sosial guru akan diikuti dengan peningkatan kepuasan orang tua peserta didik. 


\section{KESIMPULAN}

Berdasarkan dari hasil penelitian dan pembahasan tesis yang telah dilakukan, maka dapat ditarik kesimpulan Terdapat pengaruh yang positif dan signifikan antara sistem informasi manajemen pendidikan dengan kepuasan orang tua SD Al Azhar 2 Pasar Minggu. Hal ini ditunjukkan oleh kekuatan pengaruh atau koefisien korelasi sebesar 0,670 pada tingkat kepercayaan 99\% $(\alpha=0.01)$, sedangkan besarnya pengaruh atau koefisien determinasi R-square sebesar 0,449 yang menunjukkan bahwa Sistem Informasi Manajemen Pendidikan memberikan pengaruh dengan Kepuasan Orang Tua sebesar 44,9 \% dan memiliki sisa 55,1\% yang ditentukan oleh faktor lainnya. Untuk arah pengaruh atau koefisien regresi diperoleh $\hat{\mathrm{Y}}=59,045+0,567 \mathrm{X} 1$ yang menunjukkan bahwa tiap-tiap peningkatan satu unit skor sistem informasi manajemen pendidikan akan mempengaruhi semua peningkatan skor kepuasan orang tua sebesar 0,567.

Terdapat pengaruh yang positif dan signifikan antara Kompetensi Sosial Guru dengan Kepuasan Orang Tua SD Al Azhar 2 Pasar Minggu. Hal ini ditunjukkan oleh kekuatan pengaruh atau koefisien korelasi sebesar 0,546 pada tingkat kepercayaan 99\% $(\alpha=0.01)$, sedangkan besarnya pengaruh atau koefisien determinasi R-square sebesar 0,558 yang berarti bahwa Kompetensi Sosial Guru memberikan pengaruh dengan kepuasan orang tua sebesar 55,8 \% dan memiliki sisa yaitu 44,2\% yang ditentukan oleh faktor lainnya. Untuk arah pengaruh atau koefisien regresi $\hat{Y}=18,889+0,800 \mathrm{X} 2$ yang menunjukkan bahwa tiap-tiap peningkatan satu unit skor kompetensi sosial guru akan mempengaruhi semua peningkatan skor kepuasan orang tua sebesar 0,800.

Terdapat pengaruh yang positif dan signifikan antara Sistem Informasi Manajemen Pendidikan dan Kompetensi Sosial Guru secara bersama-sama dengan Kepuasan Orang Tua SD Al Azhar 2 Pasar Minggu. Hal ini ditunjukkan oleh kekuatan pengaruh atau koefisien korelasi sebesar 0,810 pada tingkat kepercayaan 99\% $(\alpha=0.01)$, sedangkan besarnya pengaruh atau koefisien determinasi R-square sebesar 0,656 yang berarti Sistem Informasi Manajemen Pendidikan dan Kompetensi Sosial Guru secara bersama-sama memberikan pengaruh dengan Kepuasan Orang Tua sebesar 65,6\% dan memiliki sisa 34,4\% yang ditentukan oleh faktor lainnya. Untuk arah pengaruh atau koefisien regresi diperoleh $\hat{\mathrm{Y}}=11,706+0,316 \mathrm{X} 1+0,581 \mathrm{X} 2$ yang menunjukkan bahwa tiap-tiap peningkatan satu unit skor sistem informasi manajemen pendidikan dan kompetensi sosial guru secara bersama-sama, akan mempengaruhi semua peningkatan skor Kepuasan Orang Tua sebesar 0,897.

\section{SARAN}

Berdasarkan hasil temuan penelitian menunjukkan adanya pengaruh yang positif dan signifikan antara sistem informasi manajemen pendidikan dan kompetensi sosial guru secara bersama- sama dengan kepuasan orang tua SD alAzhar 2 Pasar Minggu. maka peneliti menyarankan kepada manajerial sistem untuk mampu mengembangkan dan memperbanyak fitur-fitur pada sistem informasi secara terpadu yang mampu memberikan manfaat kepada orang tua dalam memperoleh informasi yang efektif dan efisien. Diharapkan orang tua mau berpartisipasi dan memanfaatkan sistem informasi yang dimiliki oleh sekolah dalam mengetahui informasi terkait dengan administrasi dan prestasi peserta didik. Kemudian guru hendaknya meningkatkan kompetensi dirinya khususnya pada kompetensi sosial, hal ini menjadi penunjang dalam peningkatan kualitas layanan sekolah, di mana guru dalam tugas dan fungsi harus mampu untuk 
berkomunikasi dan berinteraksi dengan orang tua dan masyarakat sekitar. dengan adanya pengaruh yang signifikan antara sistem informasi manajemen pendidikan dan kompetensi sosial guru terhadap kepuasan orang tua. maka pimpinan sekolah harus dapat senantiasa meningkatkan kompetensi gurugurunya dengan berbagai cara, seperti; pelatihan, seminar, dan kompetisi. kemudian senantiasa memberi motivasi dan hal-hal yang membuat guru meningkatkan keilmuan dalam memahami dalam berkomunikasi dan berinteraksi dengan orang tua maupun masyarakat sehingga kepuasan orang tua dapat tercapai dan terus meningkat.

\section{DAFTAR PUSTAKA}

Al-Fatta, Hanif, Analisis dan Perancangan Sistem Informasi untuk Keunggulan Bersaing Perusahaan dan Organisasi Modern. Yogyakarta: Andi, 2007.

Amadjati, Arista. Layanan Prima dalam Praktik Saat ini: Sistematis, Aplikatif, Disertai dengan contoh kasus dan hasil kajian pengalaman di Lapangan. Yogyakarta: Deepublish, 2018.

Amsyah, Zulkifli. Manajemen Sistem Informasi. Jakarta: Gramedia Pustaka Utama, 2005.

Baesowi, Ahmad. Calak Edu 3: Esai-esai Pendidikan 2012-2014. Tanggerang: Pustaka Alvabet, 2015.

Bashori, Khoiruddin. Pengembangan Kapasitas Guru. Tanggerang: Pustaka Alvabet, 2015.

Fattah, Nanang. Analisis Kebijakan Pendidikan. Bandung: Remaja Kosdakarya, 2014.

Fraenkel, dan Wallen, N. How to Design and evaluate research in education. New York: McGraw-Hill Inc, 1993.

Irawan, Handi. 10 Prinsip Kepuasan Pelanggan. Jakarta: Elex Media Komputindo, 2002.

McLeod, Raymond Jr. dan George P. Schell, Sistem Informasi Manajemen. Jakarta: Salemba Empat, 2006.

Mudlofir, Ali. Pendidik profesional: Konsep, Strategi dan Aplikasinya dalam Peningkatan Mutu Pendidikan di Indonesia. Jakarta: Rajawali Pers, 2012.

Mulyasa, Manajemen Berbasis Sekolah; Konsep, Strategi dan Implementasi. Bandung: Remaja Rosdakarya, 2002.

Nasution, M. N. Manajemen Mutu Terpadu. Jakarta: Ghalia Indonesia, 2004.

Rochaety, Eti dan Pontjorini Rahayuningsih. Sistem Informasi Manajemen Pendidikan. Jakarta: Bumi Aksara, 2008.

Rofa'ah. Guru dalam kegiatan pembelajaran dalam perspektif Islam. Yogyakarta: Deepublish, 2016.

Stapleton, James J. Executive' Guide To Knowledge Management: Puncak Keunggulan Kompetitif. Jakarta: Erlangga, 2003.

Sugiyono. Metode Penelitian Kuantitatif Kualitatif dan R\&D. Bandung: Alfabeta. 2012.

Supranto. Pengukuran Tingkat Kepuasan Pelanggan Untuk Menaikkan Pangsa Pasar. Jakarta: Asdi Mahasatya, 2006.

Yakub, dan Vico Hisbanarto. Sistem Informasi Manajemen Pendidikan. Yogyakarta: Graha Ilmu, 2014. 
Pengaruh Sistem Informasi Manajemen Pendidikan... |

Trihendradi C.. Step by Step SPSS 18 Analisis Data Statistik. Yogyakarta, ANDI Offset, 2010. 